\title{
Proteomic Analysis of Soybean Roots under Aluminum Stress
}

\author{
Dechassa Duressa, Khairy Soliman, Robert Taylor, and Zachary Senwo \\ Department of Natural Resources and Environmental Sciences, Alabama A\&M University, Normal, AL 35762, USA \\ Correspondence should be addressed to Dechassa Duressa, dech_1@yahoo.com
}

Received 15 November 2010; Accepted 27 January 2011

Academic Editor: Hikmet Budak

Copyright ( 12011 Dechassa Duressa et al. This is an open access article distributed under the Creative Commons Attribution License, which permits unrestricted use, distribution, and reproduction in any medium, provided the original work is properly cited.

\begin{abstract}
Toxic levels of aluminum (Al) in acid soils inhibit root growth and cause substantial reduction in yields of Al-sensitive crops. Aluminum-tolerant cultivars detoxify Al through multiple mechanisms that are currently not well understood at genetic and molecular levels. To enhance our understanding of the molecular mechanisms involved in soybean Al tolerance and toxicity, we conducted proteomic analysis of soybean roots under Al stress using a tandem combination of 2-D-DIGE, mass spectrometry, and bioinformatics tools and Al-tolerant (PI 416937) and Al-sensitive (Young) soybean genotypes at 6, 51 or $72 \mathrm{~h}$ of $\mathrm{Al}$ treatment. Comparison of the protein profile changes revealed that aluminum induced Al tolerance related proteins and enzymes in Altolerant PI 416937 but evoked proteins related to general stress response in Al-sensitive Young. Specifically, Al upregulated: malate dehydrogenase, enolase, malate oxidoreductase, and pyruvate dehydrogenase, in PI 416937 but not in Young. These enzymes contribute to increased synthesis of citrate, a key organic acid involved in Al detoxification. We postulate that simultaneous transgenic overexpression of several of these enzymes would be a robust genetic engineering strategy for developing Al-tolerant crops.
\end{abstract}

\section{Introduction}

Toxic levels of aluminum $(\mathrm{Al})$ in acid soils inhibit root growth and cause substantial reduction in yields of Alsensitive crops $[1,2]$. Its toxicity mechanisms include interference with nutrient and water uptake and translocation [3], disruption of calcium homeostatis [4], disruption of cytoskeleton $[5,6]$, callose deposition in apoplast that affects movement of substances from cell to cell [7], lipid peroxidation and reactive oxygen species production [8], and interference with cell division and elongation $[9,10]$. In concert, these disorders thwart root growth and development that is typically manifested in stunted and swollen root system at the morphological level $[11,12]$.

$\mathrm{Al}$ disrupts cellular components and processes by high binding affinity to phosphate, sulfate, and carbonyl functional groups of cellular components in apoplast and symplast [11]. Perhaps as a direct and parallel evolutionary response to the nature of Al-ligand interaction, plants secret substances that possess these functional groups namely, organic acids [13], phenolics [14-16], and phosphate and polypeptides $[17,18]$ to bind and detoxify $\mathrm{Al}$ in the rhizosphere. Sequestration of $\mathrm{Al}$ in the rhizosphere with root secreted organic acids mainly citrate, malate, and oxalate is a common and well-documented physiological mechanism of Al-tolerance in a wide variety of plants $[11,13]$. In soybean, Al-tolerance is a quantitatively inherited trait [19] and, physiologically it is correlated with root secretions of citrate $[20,21]$ and phenolics [16].

Even though the physiological and cellular responses induced by $\mathrm{Al}$ stress are direct consequences of change in gene expression and cell metabolism, the genetic components of Al-tolerance pathways are not well understood. Monitoring protein expression changes under $\mathrm{Al}$ stress is one possible way of identifying the genetic and molecular components underlying $\mathrm{Al}$-tolerant phenotype. A few research groups have conducted proteome analysis in plant roots under Al stress [22-24]. These studies consistently identified antioxidation and detoxification enzymes and proteins as important determinants of plant Al-tolerance trait. Their limitation, however, is that nonutilized tolerantsensitive genotype pair that would ensure the specificity of the identified proteins to Al-tolerance mechanism. We previously examined $\mathrm{Al}$-induced protein profile changes in 
roots of Al-tolerant and Al-sensitive soybean genotypes [16], but did not pursue functional annotation of the differentially expressed proteins. In the present study, we combined 2D DIGE differential expression, mass spectrometry, and bioinformatics tools to characterize the proteome profile changes in Al-tolerant and Al-sensitive soybean genotypes with the aim of identifying potential biomarkers for soybean Al-tolerance. Our results suggest that organic acid biosynthesis and antioxidation and detoxification enzymes play important role in soybean Al-tolerance.

\section{Materials and Methods}

2.1. Plant Growth Condition, Root Sampling, and Protein Extraction. Two soybean genotypes PI 416937 (Al-tolerant) and Young (Al-sensitive) were used in the study. Seeds were surface sterilized with 20\% household bleach (Clorox) in water for $12 \mathrm{~min}$, rinsed with distilled-deionized water several times and were germinated in standard germination paper at $25^{\circ} \mathrm{C}$ in an incubator for $72 \mathrm{~h}$. Three-day-old seedlings uniform in tap root length were transferred to black-painted pots filled with approximately $4 \mathrm{~L}$ of $800 \mu \mathrm{M}$ $\mathrm{CaCl}_{2}$ background solution with $10 \mu \mathrm{M} \mathrm{Al}$ added (treated) or no $\mathrm{Al}$ added (control) in a Conviron growth chamber ( $16 / 8 \mathrm{~h}$ light/dark cycle with respective temp. of $28^{\circ} \mathrm{C} / 20^{\circ} \mathrm{C}$, photosynthetic photon density of $\left.100 \mu \mathrm{mol} \mathrm{m} \mathrm{m}^{-2} \mathrm{~s}^{-1}\right)$. The $\mathrm{pH}$ of the culture solution was adjusted to 4.3 and maintained at that level for the entire duration of the experiment. After 6,51 , or $72 \mathrm{~h}$ of $\mathrm{Al}$ treatment primary roots and laterals of (see supplementary Figure 1, available online at doi:10.1155/2011/282531, for representative root picture) approximately 15 plants/pot were harvested and immediately flash frozen in liquid nitrogen, stored at $-70^{\circ} \mathrm{C}$ until protein extraction. Protein was extracted using the phenol method [25], and protein concentrations of samples were determined using the Bradford method [26].

\subsection{D DIGE Analysis}

2.2.1. Sample Preparation and CyDye Labeling. Protein samples were dissolved in $300 \mu \mathrm{L}$ of $2 \mathrm{D}$ cell lysis buffer $(30 \mathrm{mM}$ Tris- $\mathrm{HCl}, \mathrm{pH} 8.8$, containing $7 \mathrm{M}$ urea, $2 \mathrm{M}$ thiourea and $4 \%$ CHAPS) and sonicated at $4^{\circ} \mathrm{C}$ followed by shaking for $30 \mathrm{~min}$ at room temperature. Samples were then centrifuged for $30 \mathrm{~min}$ at $14,000 \mathrm{rpm}$ and the supernatant collected. An internal standard for assay normalization was created by mixing equal amounts of protein from each sample. For each sample, $30 \mu \mathrm{L}$ of protein was mixed with $1.0 \mu \mathrm{L}$ of diluted CyDye and kept in the dark on ice for $30 \mathrm{~min}$. Proteins from the control and treated samples were labeled with Cy3 and Cy5, respectively, whereas the internal standard was labeled with Cy2. The labeling reaction was stopped by adding $1.0 \mu \mathrm{L}$ of $10 \mathrm{mM}$ Lysine and incubation in the dark on ice for an additional $15 \mathrm{~min}$. The labeled samples from the control and treated groups and the internal standard were blended for a run of three samples per gel. The $2 \mathrm{X} 2 \mathrm{D}$ sample buffer (8 M urea, 4\% CHAPS, $20 \mathrm{mg} / \mathrm{mL}$ DTT, 2\% pharmalytes, and trace amount of bromophenol blue), $100 \mu \mathrm{L}$ of destreak solution, and rehydration buffer (7 M urea, $2 \mathrm{M}$ thiourea, 4\%
CHAPS, $20 \mathrm{mg} / \mathrm{mL}$ DTT, 1\% pharmalytes, and trace amount of bromophenol blue) were added to the labeling mix to a total volume of $250 \mu \mathrm{L}$. The mixture was mixed well and spinned before loading samples into strip holder.

2.2.2. IEF and SDS-PAGE. IEF ( $\mathrm{pH}$ 3-10 Linear) was run following the protocol of Amersham BioSciences. After IEF, the IPG strips were incubated in fresh equilibration buffer1 (50 mM Tris- $\mathrm{HCl}, \mathrm{pH}$ 8.8, containing $6 \mathrm{M}$ urea, $30 \%$ glycerol, 2\% SDS, trace amount of bromophenol blue and $10 \mathrm{mg} / \mathrm{mL}$ DTT) for $15 \mathrm{~min}$ with gentle shaking. The strips were then rinsed in fresh equilibration buffer-2 $(50 \mathrm{mM}$ Tris$\mathrm{HCl}, \mathrm{pH} 8.8$, containing $6 \mathrm{M}$ urea, 30\% glycerol, $2 \%$ SDS, trace amount of bromophenol blue and $45 \mathrm{mg} / \mathrm{mL}$ DTT) for 10 min with slow shaking. Afterwards, the IPG strips were rinsed with the SDS-gel running buffer and transferred to $12 \%$ SDS-gel. SDS-gels were run at $15^{\circ} \mathrm{C}$ until the dye front began running out of the gel.

2.2.3. Image Scan and Data Analysis. Gel images were scanned immediately following the SDS-PAGE using Typhoon TRIO (Amersham BioSciences). The scanned images were then analyzed by Image Quant software (version 6.0, Amersham BioSciences). The fold changes of protein expression levels were obtained from Biological Variation Analysis (BVA) using the DeCyder software version 6.5 (Amersham BioSciences).

\subsection{Protein Identification by Mass Spectrometry}

\subsubsection{Spot Picking, Trypsin Digestion and Mass Spectrometry.} The spots of interest were picked by Ettan Spot Picker (Amersham BioSciences) based on the in-gel analysis and spot picking design by DeCyder software. The gel spots were washed few times and digested in-gel with modified porcine trypsin protease (Trypsin Gold, Promega). The digested tryptic peptides were desalted by Zip-tip C18 (Millipore). Peptides were eluted from the Zip-tip with $0.5 \mu \mathrm{L}$ of matrix solution of cyano-4-hydroxycinnamic acid ( $5 \mathrm{mg} / \mathrm{ml}$ in $50 \%$ acetonitrile, $0.1 \%$ trifluoroacetic acid, $25 \mathrm{mM}$ ammonium bicarbonate) and spotted on the MALDI plate (model ABI 01-192-6-AB). MALDI-TOF MS and TOF/TOF tandem MS/MS were performed on an ABI 4700 mass spectrometer (Applied Biosystems, Framingham, MA). MALDI-TOF mass spectra were acquired in reflectron positive ion mode, averaging 4000 laser shots per spectrum. TOF/TOF tandem MS fragmentation spectra were acquired averaging 4000 laser shots per fragmentation spectrum on each of the 5 to 10 most abundant ions present in each sample, excluding trypsin autolytic peptides and other known background ions.

2.4. Database Search. The peptide mass and the associated fragmentation spectra were submitted to GPS explorer workstation equipped with MASCOT search engine (Matrix science) to search the database of National Center for Biotechnology Information non-redundant protein database (NCBInr). Searches were performed without constraining protein molecular weight or isoelectric point, with 


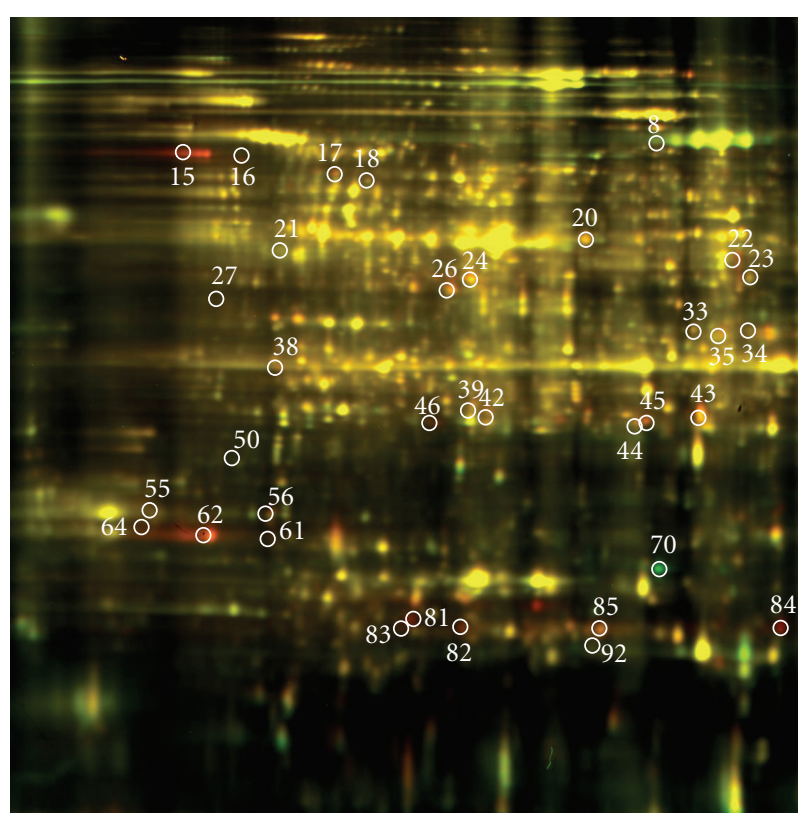

FIGURE 1: 2D profile of aluminum regulated-proteins in PI 416937 $72 \mathrm{~h}$ posttreatment.

variable carbamidomethylation of cysteine and oxidation of methionine residues, and with one missed cleavage also allowed in the search parameters. Mass tolerances of $100 \mathrm{ppm}$ for the precursor ion and $0.3 \mathrm{Da}$ for fragment ion were used as constraints to control false positives. Candidates with $\mathrm{CI} \%$ greater than 95 either for protein or ion score, or $E$-value less than $\mathrm{e}^{-10}$ and \% identity greater than 30 when blasted against soybean protein database (http://www.phytozome.net/soybean) were considered significant. For peptide data summary and protein prediction significance criteria, see supplementary Tables 1 and 2.

\section{Results and Discussion}

3.1. Al-Responsive Proteins Identified By MALDI-TOF-TOF Mass Spectrometry. Three criteria were used to identify Al-responsive proteins among hundreds of protein spots resolved by 2-DIGE gel to assure data quality: (1) expression fold change of at least 1.3, either up- or downregulation, at least at one of the time points in Al-treated versus control comparison, (2) presence in all replicates, and (3) standard error less than the mean. A total of 49 proteins in Altolerant PI 416937 (Table 1) and 47 proteins in Al-sensitive Young (Table 2) met these criteria and were subsequently identified by mass spec (see Figures 1 and 2, e.g., 2D profile of the identified proteins). In PI 416937, 1, 29, 30 proteins were upregulated at 6,51 , and $72 \mathrm{~h}$, respectively (Figure 3), whereas in Young 4, 7, 36 proteins were upregulated at 6 , 51 , and $72 \mathrm{~h}$, respectively (Figure 4). Downregulated proteins were 5 each at 51 and $72 \mathrm{~h}$ in PI 416937 (Figure 3) and 5, 3, 7 in Young at 6, 51, and $72 \mathrm{~h}$, respectively (Figure 4 ). In both genotypes, there were more upregulated than downregulated proteins, and more proteins were detected at later stages

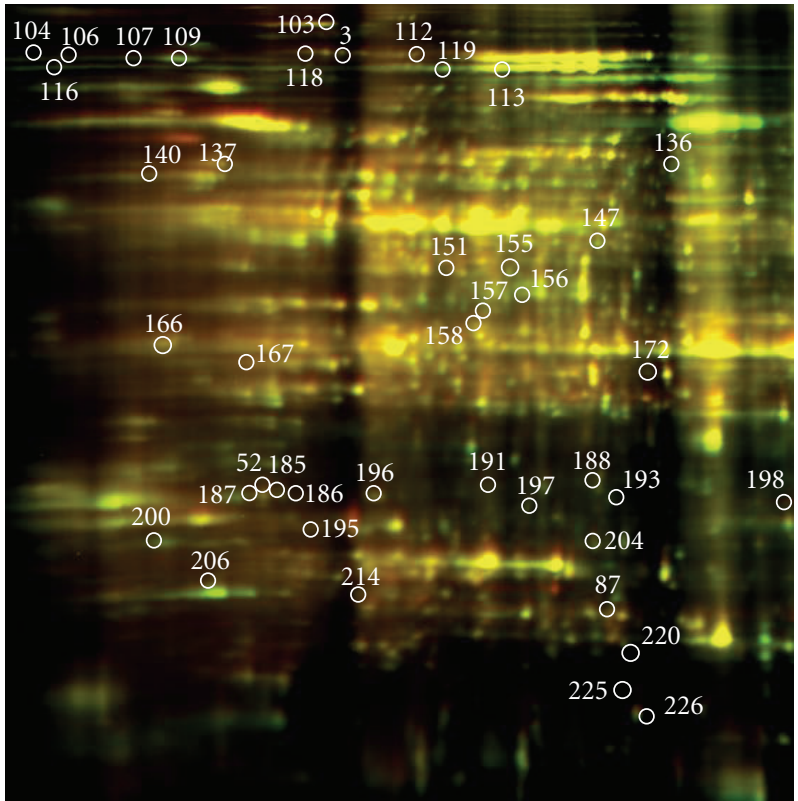

Figure 2: 2D profile of aluminum regulated-proteins in Young $72 \mathrm{~h}$ posttreatment.

of $\mathrm{Al}$ stress than during the early hours of exposure to Al. There were more common proteins between time points in PI 416937 than in Young (Figure 5).

In Young, a major change in protein profile was observed $72 \mathrm{~h}$ posttreatment, whereas in PI416937 major change in protein expression was observed starting at $51 \mathrm{~h}$ of treatment. In addition to the difference in the timing of the molecular response to $\mathrm{Al}$ stress between the two genotypes, there was a clear difference in the identity of the expressed proteins as well. Al upregulated several important $\mathrm{Al}-$ tolerance proteins (pyruvate dehydrogenase, spot no. 35; malate dehydrogenase, spot no. 42; malate oxidoreductase, spot no.18; and enolase, spot no. 20; cysteine synthase, spot no.39; isoflavone biosynthesis enzyme-NADPH: isoflavone reductase, spot no. 46; dehydroascorbate reductase, spot no. 89) (Table 1), in the Al-tolerant PI 416937. Conversely, aluminum induced mainly non-Al-specific general stress tolerance proteins in the Al-sensitive Young. This might explain the phenotypic difference in Al-tolerance between the two genotypes. Nonetheless, Vacoular ATpase (V-ATPase)—a known Al-tolerance transport protein (spot no. 155, Table 2) was upregulated 1.3 -fold at $72 \mathrm{~h}$ in Young indicating that Young may possess some basal tolerance mechanism to aluminum toxicity as suggested by Bianchi-Hall et al. [19].

3.2. Functional Classification of Al-Responsive Proteins. The identified proteins were grouped into 13 classes based on cellular function according to the classification scheme in Houston et al. [27]. The distribution of the proteins over functional classes revealed that Al-responsive proteins in PI 416937 are more of proteins of primary metabolism, disease/defense, energy and signal transduction with $16 \%$ in 
TABle 1: Aluminum regulated-proteins detected in soybean line PI 416937 in time-course Al stress experiment.

\begin{tabular}{|c|c|c|c|c|c|c|c|c|}
\hline \multirow{2}{*}{ Spot } & \multirow{2}{*}{ Accession } & \multirow{2}{*}{ Protein ID/functional class ${ }^{\mathrm{a}}$} & \multicolumn{6}{|c|}{ Average expression fold change ${ }^{b}$} \\
\hline & & & $6 \mathrm{~h}$ & SE & $51 \mathrm{~h}$ & SE & $72 \mathrm{~h}$ & SE \\
\hline 5 & gi/126411 & Lipoxygenase $(P M)$ & -1.04 & 0 & -1.43 & 0.09 & -1.25 & 0.07 \\
\hline 8 & gi/42820320 & Copper amino oxidase (DD) & -1.04 & 1.05 & -1.53 & 0.02 & -2.24 & 0.08 \\
\hline 15 & gi/225425555 & Thioredoxin (DD) & 1.11 & 0.02 & 3.01 & 0.07 & 4.34 & 1.04 \\
\hline 16 & gi/224115920 & Protein phosphatase $2 A(S T)$ & 1.13 & 0 & 1.83 & 0.14 & 3.05 & 0.4 \\
\hline 17 & gi/22331670 & Serine/threonine protein kinase (ST) & -1.24 & 0.12 & 1.14 & 0.06 & 1.47 & 0.05 \\
\hline 18 & gi/15225438 & Malate oxidoreductase (E) & -1.13 & 0.07 & 1.10 & 0.04 & 1.33 & 0.04 \\
\hline 20 & gi/162458207 & Enolase $(E)$ & 1.07 & 0.04 & 1.04 & 1.12 & 1.39 & 0.03 \\
\hline 21 & gi/223548395 & $26 S$ protease subunit $6 a(P D)$ & -1.13 & 0.01 & -1.29 & 0.04 & -1.31 & 0.19 \\
\hline 22 & gi/2511541 & DNA-binding protein gbp16 (UN) & 1.03 & - & 1.48 & 0.21 & 1.90 & 0.23 \\
\hline 23 & gi/4836923 & CREB binding protein $(T F)$ & -1.05 & 0.03 & -1.08 & 1.21 & 1.38 & 0.14 \\
\hline 24 & gi/223548531 & S-adenosyl methionine synthase (PM) & 1.13 & 1.17 & 1.41 & 0.35 & 1.45 & 0.14 \\
\hline 25 & gi/224285989 & Amidase/tetratricopeptide repeat (PM) & -1.08 & 0.14 & 1.62 & 0.07 & nd & - \\
\hline 26 & gi/3024127 & S-adenosyl methionine synthase (PM) & 1.11 & 0.06 & 1.35 & 0.23 & 1.50 & 0.26 \\
\hline 27 & gi/223548639 & Transaldolase $(P M)$ & 1.07 & 0.02 & 1.16 & 0.01 & 1.43 & 0.14 \\
\hline 30 & gi/211970690 & Formate dehydrogenase (PM) & 1.14 & 0.01 & 1.45 & 0.17 & 1.22 & 0.21 \\
\hline 31 & gi/1498340 & $\operatorname{Actin}(C S)$ & 1.06 & 0.02 & 1.35 & 0 & 1.05 & 1.37 \\
\hline 33 & gi/157346459 & NADH:flavin oxidoreductase (DD) & 1.05 & 1.08 & 1.49 & 0.09 & 1.30 & 0.1 \\
\hline 34 & gi/242462 & Lipoxygenase $(P M)$ & nd & - & 1.71 & 0.08 & 1.62 & 0.3 \\
\hline 35 & gi/195637880 & Pyruvate dehydrogenase E1 (E) & 1.02 & 1.03 & 1.30 & 0.04 & 1.30 & 0.01 \\
\hline 36 & gi/9230771 & Cyt phosphoglysrate kinase (PM) & nd & - & 1.59 & 0.21 & 1.27 & 0.11 \\
\hline 37 & gi/49257111 & Disulfide isomerase-like (PD) & -1.12 & 1.26 & -1.63 & 0.02 & 1.02 & 1.32 \\
\hline 38 & gi/168029670 & Unknown $(U N)$ & nd & - & nd & - & 1.61 & 0.38 \\
\hline 39 & gi/126508778 & Cystine synthase (PM) & 1.08 & 0.04 & 1.40 & 0.16 & 1.46 & 0.16 \\
\hline 42 & gi/3273828 & Malate dehydrogenase (E) & 1.03 & 1.1 & 1.87 & 0.55 & 2.05 & 0.62 \\
\hline 43 & gi/186506243 & Aaldo/keto reductase (PM) & 1.14 & 0.06 & 1.52 & 0.1 & 1.48 & 0.27 \\
\hline 44 & gi/34559418 & (+)-pulegone reductase (SM) & 1.09 & 1.15 & 1.31 & 0.24 & 1.43 & 0.26 \\
\hline 45 & gi/108864466 & Unknown $(U N)$ & nd & - & 1.64 & 0 & 1.85 & 0.09 \\
\hline 46 & gi/2687724 & NADPH:isoflavone reductase (SM) & 1.24 & 0.22 & nd & - & 2.17 & 0.33 \\
\hline 50 & gi/393401 & Alpha tubulin (CS) & 1.09 & 0.07 & -1.45 & 0.05 & -1.30 & 0.09 \\
\hline 55 & gi/3023196 & 14-3-like protein C (ST) & nd & - & nd & - & 1.41 & 0.27 \\
\hline 56 & gi/6469121 & Plasma membrane polypeptide (UN) & nd & - & nd & - & 1.30 & 0.07 \\
\hline 61 & gi/186507172 & BRCA1 C terminal $(C D)$ & 1.09 & 0.04 & 1.21 & 0.04 & 1.41 & 0.01 \\
\hline 62 & gi/6690745 & Resistance protein (DD) & nd & - & nd & - & 3.81 & 0.04 \\
\hline 64 & gi/3023194 & 14-3-3-like protein A (ST) & 1.11 & 0.08 & -1.15 & 0.06 & 1.60 & 2.11 \\
\hline 65 & gi/125550993 & Unknown (UN) & 1.00 & 1.01 & -1.48 & 0.02 & -1.28 & 0 \\
\hline 67 & gi/225455804 & Hypothetical protein (UN) & 1.04 & 1.09 & 1.61 & 0.12 & 1.22 & 0.03 \\
\hline 70 & gi/226866 & 31 kD protein $(U N)$ & 2.19 & 0.67 & -1.28 & 1.81 & -1.31 & 4.14 \\
\hline 75 & gi/11385431 & Glutathione S-transferase 8 (DD) & -1.04 & 1.06 & 1.39 & 0.07 & 1.16 & 1.17 \\
\hline 78 & gi/224087343 & WD40 protein/RNA processing $(T F)$ & -1.06 & 1.15 & 1.34 & 0.15 & 1.18 & 0.02 \\
\hline 79 & gi/194705252 & Cytidyly transferase (SM) & -1.25 & 0.08 & 1.64 & 0.24 & 1.00 & 0.9 \\
\hline 81 & gi/1170781 & Glutathatione-S-transferase 3 (DD) & 1.10 & 1.64 & 4.05 & 0.92 & 2.27 & 2.03 \\
\hline 82 & gi/11385435 & Glutathione-S-transferase 10 (DD) & 1.12 & 1.23 & 2.30 & 0.16 & 1.63 & 0.75 \\
\hline 83 & gi/399240 & $20 \mathrm{kDa}$ chaperonin (UN) & -1.02 & 1.39 & 2.29 & 0.33 & 1.54 & 2.14 \\
\hline 84 & gi/224135489 & Beta glucosidase (PM) & 1.16 & 0.03 & nd & - & 4.02 & 0.48 \\
\hline 85 & gi/11385459 & Gluthstione-S-transferase 22 (DD) & -1.07 & 1.16 & 1.55 & 0.01 & 1.59 & 0.26 \\
\hline 89 & gi/28192427 & Dehydroascorbate reductase (DD) & 1.09 & 0.049 & 1.35 & 0.05 & -1.08 & 1.62 \\
\hline 90 & gi/30682123 & Adenine phosphoribosyl transferase, ATP4 (PM) & 1.24 & 0.01 & 1.38 & 0.02 & nd & - \\
\hline 91 & gi/17380185 & Proteasome subunit beta-1 (PD) & -1.07 & 1.16 & 1.42 & 0.14 & nd & - \\
\hline 92 & gi/21068664 & Quinine oxidoreductase (DD) & 1.21 & 0.01 & -1.20 & 0.14 & -1.31 & 0.14 \\
\hline
\end{tabular}

a PM: primary metabolism, SM: secondary metabolism, E: energy, PD: protein destination, TF: transcription factor, CS: cell structure, ST: signal transduction, DD: disease/defense, CD: cell division, UN: unknown function;

b expression fold change at each time point, negative values: downregulation, positive values: upregulation, fold change significance cut-off is \pm 1.3 , SE: standard error, nd: not detected. 
TABLE 2: Aluminum regulated-proteins detected in soybean cultivar Young in time-course Al stress Experiment.

\begin{tabular}{|c|c|c|c|c|c|c|c|c|}
\hline \multirow{2}{*}{ Spot } & \multirow{2}{*}{ Accession } & \multirow{2}{*}{ Protein ID/functional class ${ }^{\mathrm{a}}$} & \multicolumn{6}{|c|}{ Average expression fold change ${ }^{b}$} \\
\hline & & & $6 \mathrm{~h}$ & SE & $51 \mathrm{~h}$ & SE & $72 \mathrm{~h}$ & SE \\
\hline 3 & gi/27883937 & Phosphoribosylformayl glycinamidine synthase (PM) & -1.34 & 0.13 & 1.33 & 0.10 & 1.45 & 0.20 \\
\hline 52 & gi/224160640 & Zinc Knuckle (UN) & 1.24 & 0.18 & nd & 0.17 & 1.67 & 0.17 \\
\hline 87 & gi/11385431 & Glutathione (DD) & nd & - & 1.22 & 0.08 & 4.34 & 1.04 \\
\hline 100 & gi/156938901 & Profilin/actin binding (CS) & 1.92 & 0.8 & nd & - & nd & - \\
\hline 103 & gi/79321519 & Heat shock protein $70(P D)$ & -1.02 & 1.10 & 1.08 & 1.10 & 1.44 & 0.06 \\
\hline 104 & gi/153805634 & Unknown $(U N)$ & nd & - & nd & - & 1.38 & 0 \\
\hline 106 & gi/15219879 & Apoptotic ATpase (DD) & -1.08 & 0.01 & 1.15 & 0.11 & 1.44 & 0.10 \\
\hline 107 & gi/30696901 & Xylose isomerase (PM) & 1.05 & 0.01 & nd & - & 1.37 & 0.09 \\
\hline 109 & gi/168030956 & Serine/threonine $\backslash$ protein kinase (ST) & nd & - & nd & - & 1.31 & 0.04 \\
\hline 112 & gi/436169 & Lipoxygenase $(P M)$ & -1.10 & 0.03 & 1.13 & 0.05 & 1.35 & 0.23 \\
\hline 113 & gi/77552532 & Unknown (UN) & -1.52 & 0.62 & 1.21 & 0.06 & 1.38 & 0.18 \\
\hline 116 & gi/2232254 & NADH:flavin oxidoreductase (UN) & -1.36 & 0.06 & nd & & 1.49 & 0.18 \\
\hline 118 & gi/223541365 & Transitional endoplasmic reticulum ATPase (CS) & nd & - & 1.37 & 0.03 & 1.37 & 0.27 \\
\hline 119 & gi/223974443 & Unknown (UN) & -1.05 & 0.01 & -1.03 & 1.07 & 1.31 & 0 \\
\hline 133 & gi/42820320 & Copper amino oxidase (DD) & 1.03 & 1.05 & nd & - & 1.35 & 0.07 \\
\hline 136 & gi/195636596 & T-complex protein 1 alpha (PD) & 1.06 & 0.02 & 1.35 & 0 & 1.05 & 1.37 \\
\hline 137 & gi/125574688 & Glutathione-s-transferase (DD) & 1.19 & 0.17 & 1.21 & 0.08 & 1.33 & 0.35 \\
\hline 140 & gi/74053562 & Tubulin beta-3-chain (CS) & -1.03 & 0.01 & 1.02 & 0.08 & 1.62 & 0.3 \\
\hline 147 & gi/5225811 & Unknown (UN) & 1.03 & 0.03 & 1.05 & 1.06 & -1.39 & 0.01 \\
\hline 151 & gi/124112056 & Septum site determining protein (CS) & nd & - & 1.52 & 0.53 & -1.36 & 0.05 \\
\hline 155 & gi/87240711 & $V$-ATPase subunit C (DD) & nd & - & nd & - & 1.31 & 0.23 \\
\hline 156 & gi/1346698 & Phosphoglycerate kinase (PM) & -1.03 & 0 & 1.14 & 1.20 & 1.45 & 0.54 \\
\hline 157 & gi/1582580 & Caffeic acid O-methyl transferase (SM) & -1.04 & 1.06 & nd & - & 1.35 & 0.09 \\
\hline 158 & gi/1346028 & Polyprenyl synthetase (SM) & 1.09 & 1.09 & 1.06 & 0.04 & 1.32 & 0.05 \\
\hline 166 & gi/3023197 & 14-3-like $(S T)$ & nd & - & 1.09 & 0.04 & -1.32 & 0.23 \\
\hline 167 & $\mathrm{gi} / 393401$ & Alpha tubulin (CS) & 1.21 & 0 & 1.41 & 0.06 & -1.42 & 0.20 \\
\hline 172 & gi/78146198 & MADS box protein/transcription factor (TF) & 1.11 & 0.11 & nd & - & 1.85 & 0.74 \\
\hline 185 & gi/115511406 & Acirduyctase dioxygenase (PM) & 1.25 & 0.13 & nd & - & 1.61 & 0.01 \\
\hline 186 & gi/224105487 & Unknown (UN) & 1.11 & 1.22 & 1.22 & 0.21 & 1.34 & 0 \\
\hline 187 & gi/145352433 & Unknown $(U N)$ & -1.01 & 1.02 & 1.44 & 0.01 & 1.59 & 0.25 \\
\hline 188 & gi/17380185 & Proteasome subunit beta type-1 (PD) & 1.04 & 0.02 & nd & - & 1.72 & 0.11 \\
\hline 191 & gi/223543735 & Proteasome subunit beta type (PD) & -1.04 & 0.02 & nd & - & 1.74 & 0.52 \\
\hline 193 & gi/145340582 & Unknown $(U N)$ & 1.08 & 0 & nd & - & 1.41 & 0.08 \\
\hline 195 & gi/209778987 & Putative rab1C protein (IT) & -1.05 & 1.15 & -1.02 & 1.10 & -1.67 & 0.29 \\
\hline 196 & gi/18395025 & $20 S$ proteasome beta subunit $C(P D)$ & 1.07 & 1.16 & nd & - & 1.32 & 0.27 \\
\hline 197 & gi/125577605 & DNJ/HSP40 (DD) & 1.04 & 1.16 & 1.00 & 1.07 & 1.35 & 0.31 \\
\hline 198 & gi/34485411 & Resistance protein (DD) & 1.00 & 1 & 1.40 & 0.06 & 1.73 & 0.37 \\
\hline 200 & gi/20140683 & Translationally-controlled tumor protein homolog (CD) & nd & - & -1.53 & 0.08 & -1.46 & 0.10 \\
\hline 201 & gi/40644130 & Allene oxide cyclase (PM) & -1.51 & 0.47 & nd & - & 1.59 & 0.26 \\
\hline 204 & gi/223510245 & Unknown (UN) & 1.04 & 0.04 & 1.01 & 1.17 & 1.32 & 0.05 \\
\hline 206 & gi/197294157 & Hypothetical protein (UN) & -1.53 & 0.55 & nd & - & 1.42 & 0.22 \\
\hline 212 & gi/110931690 & MYB transcription factor $(T F)$ & 1.39 & 0.38 & -1.93 & 0.75 & nd & - \\
\hline 214 & gi/18143656 & $\operatorname{Mcp} 20(P D)$ & 1.35 & 0.18 & nd & - & 1.61 & 0.73 \\
\hline 218 & gi/829282 & Eukaryotic initiation factor A (PS) & 1.93 & 0.46 & nd & - & nd & - \\
\hline 220 & gi/15238219 & Unknown $(U N)$ & nd & - & -1.32 & 0.08 & -1.72 & 0.08 \\
\hline 225 & gi/223547693 & Electron transporter $(E)$ & nd & - & -1.02 & 1.07 & 2.10 & 0.20 \\
\hline 226 & gi/145345251 & Glycogen synthase kinase-3 (PM) & nd & - & nd & - & 1.77 & 0.21 \\
\hline
\end{tabular}

aPM: primary metabolism, SM: secondary metabolism, E: energy, PD: protein destination, TF: transcription factor, CS: cell structure, ST: signal transduction, DD: disease/defense, t, IT: intracellular trafficking, CD: cell division, UN: unknown function;

$\mathrm{b}$ expression fold change at each time point, negative values: downregulation, positive values: upregulation, fold change significance cut-off is \pm 1.3 , SE: standard error, nd: not detected. 


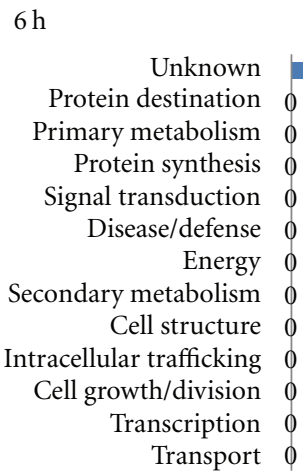

Number of proteins

(a)

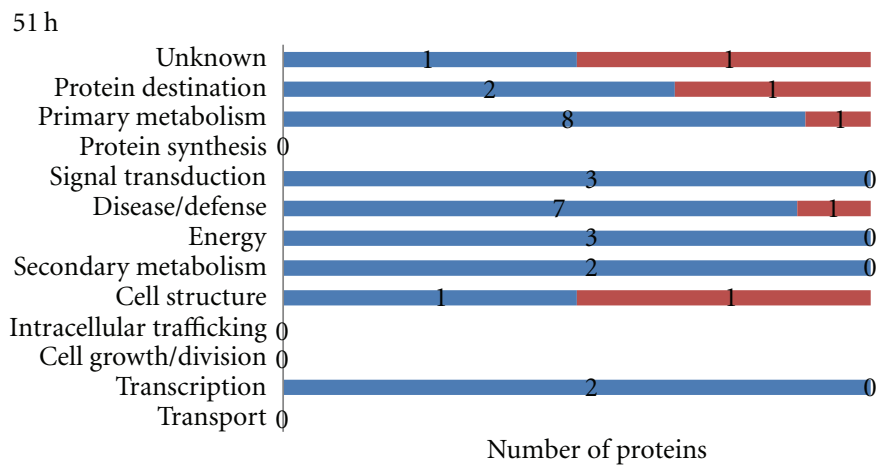

(b)

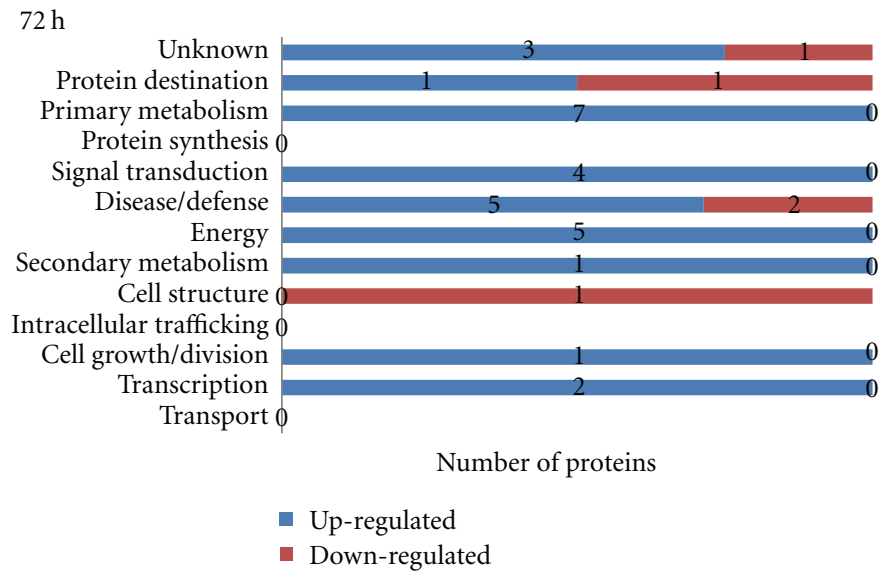

(c)

FIGURE 3: Functional class distribution of aluminum upregulated and downregulated proteins in PI 416937 in time-course experiment.

the unknown class (Figure 3); and in Young Al-responsive proteins are more of proteins of primary metabolism, disease/defense and protein destination with $26 \%$ in the unknown class (Figure 4). In discussion of this paper, the disease/defense category was renamed as antioxidation and detoxification and the energy category as organic acid biosynthesis enzymes to easily connect these proteins to physiologically known plant Al-tolerance mechanisms.

3.3. Antioxidation and Detoxification Proteins. Al toxicity induces production of reactive oxygen species (ROS) in cells beyond the level generated by normal metabolism as one mode of its toxicity $[8,12,23]$. Plants have elaborate enzymatic and nonenzymatic mechanisms for ROS scavenging and variation in plant antioxidant capacity has been shown to correlate with variation in plant Al-tolerance level [28]. Several known antioxidation and detoxification enzymes including thioredoxin (Spot 15), lactoyl glutathione lyase (spot 81), three isoforms of glutathione-S-transferase (GST) (spots 75, 82, and 85), dehydroascorbate reductase (spot 89), cysteine synthase (spot 39), aldo/keto reductase (spot 43) and NADH: isoflavone reductase (spot 46) were upregulated 
$6 \mathrm{~h}$

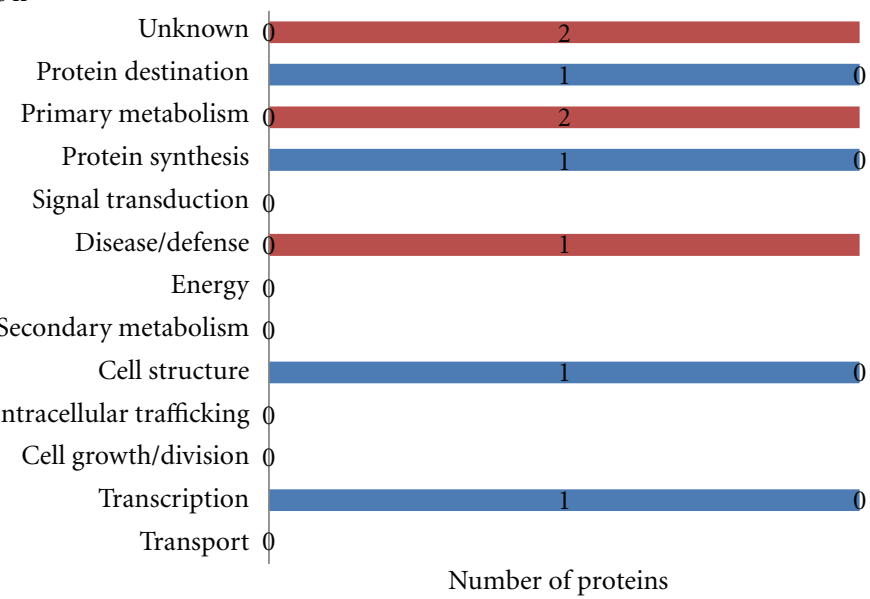

(a)

$51 \mathrm{~h}$

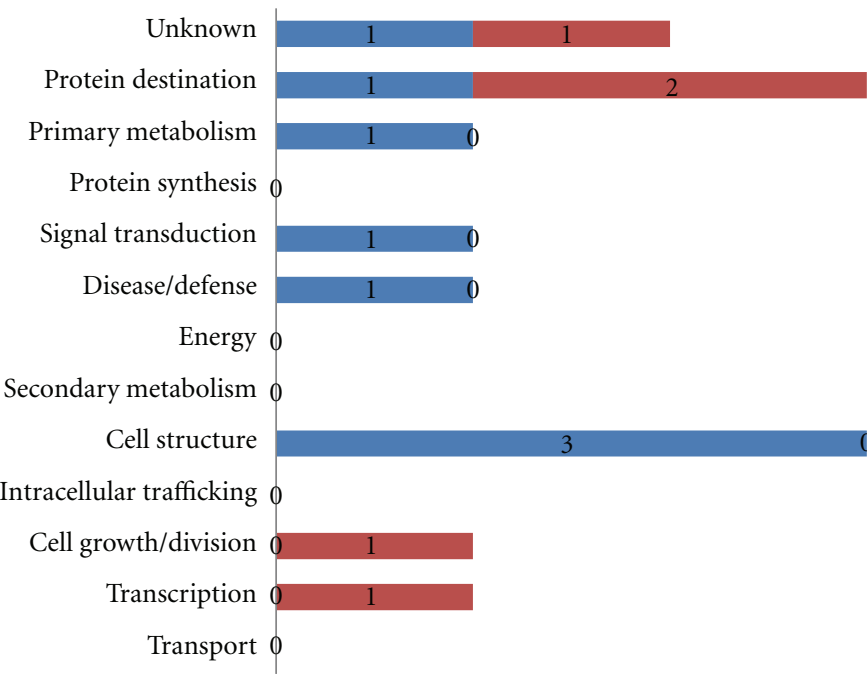

Number of proteins

(b)

$72 \mathrm{~h}$

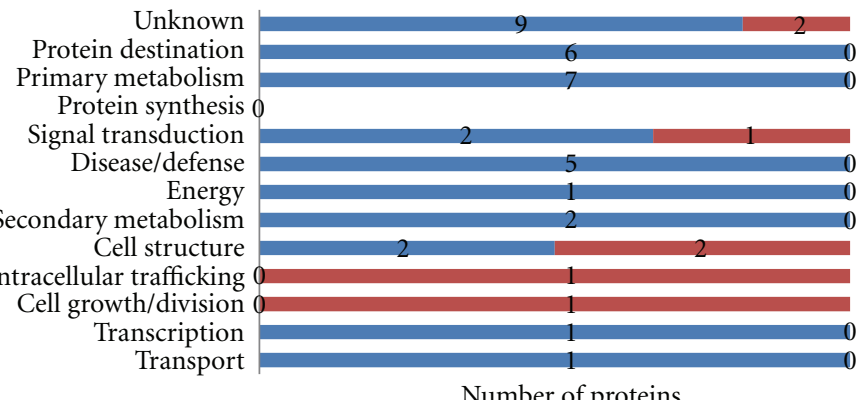

- Up-regulated

- Down-regulated

(c)

FIGURE 4: Functional class distribution of aluminum upregulated and downregulated proteins in Young in time-course experiment. 


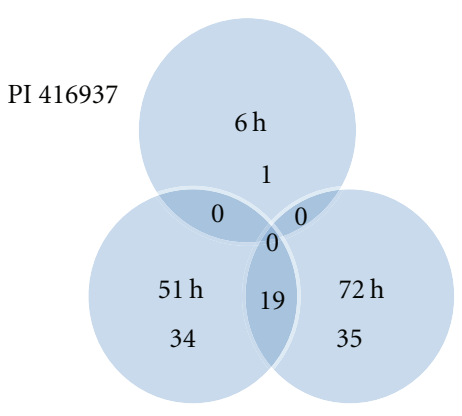

(a)

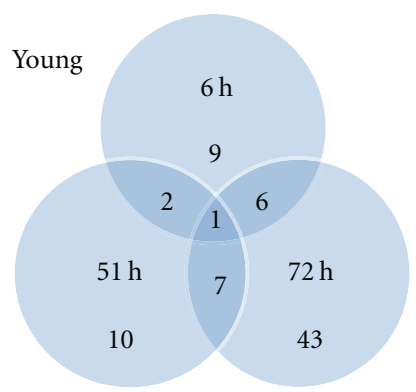

(b)

FIGURE 5: Number of proteins detected at each time points. Numbers in the intersections denote number of proteins in common between or among the time points.

in Al-tolerant PI 416937 (Table 1). None of these enzymes except glutathione-S-transferase (GST) was upregulated in $\mathrm{Al}$-sensitive Young. Earlier proteome analysis in Al-tolerant varieties of rice [22], soybean [24], and tomato [12, 23] suggest that antioxidation and detoxification enzymes play an important role in internal Al-tolerance mechanism. PI 416937 accumulates less Al than Young in symplast [29] and, as revealed by the current study, appears to have better antioxidant and detoxification capacity implying that it employs both the exclusion and internal detoxification mechanisms of Al-tolerance.

Among the antioxidation and detoxification enzymes differentially expressed between PI 416937 and Young, it is interesting to highlight the $\mathrm{Al}$ detoxification role of cysteine synthase, GST, and NADPH: isoflavone reductase. There is increasing evidence for the synergetic effect of cysteine synthase and GST in conferring plant Al-tolerance [12, 22, 24]. Cysteine, the byproduct of cysteine synthase catalyzed reaction, is a precursor for glutathione synthesis (GSH) which in turn is a key substrate for biosynthesis of metallothionin (MT) and phytochelatin- (PC-) low molecular weight peptides known to confer heavy metal tolerance in plants [30]. MT has been reported to be induced by Al stress probably as a tolerance mechanism [24]. In addition to its role in MT and PC biosynthesis, GSH is directly involved in detoxification of Al-elicited toxins in concert with GST. GST transfers GSH to such substances forming s-gluthionaylated reaction products that are nontoxic to the cell [31]. Further, reduced glutathione has an antioxidant property capable of scavenging Al-triggered ROS. Therefore, the concomitant upregulation of cysteine synthase and glutathione-Stransferases in Al-tolerant PI416937 is suggestive of the significance of antioxidation and detoxification proteins in protecting this soybean type from $\mathrm{Al}$-induced oxidative stress and endogenous toxins. NADPH: isoflavone reductase is involved in isoflavone synthesis. Flavonoids confer Altolerance via the dual mechanisms of $\mathrm{Al}$ chelation and antioxidation [18]. At the physiological level, a positive correlation between root flavonoids and phenolics secretion and plant Al-tolerance has been documented [14-16].

3.4. Cell Structure and Cell Division-Related Proteins. Plant cells require dynamic actin- andtubulin-based networks for proliferation and differentiation [32]. Aluminum stabilizes, depolymerizes, and alters the orientation of cytoskeleton networks resulting in inhibition of cell division, elongation and consequently root growth $[5,6,33,34]$. Whether this phenomenon is a direct outcome of Al-interaction with cytoskeletal structure or by its indirect influences on factors that control cytoskeletal assembly and disassembly is not known [6]. The expression of cytoskeleton proteins has been proposed to be one of the primary targets of $\mathrm{Al}$ toxicity [33]. Al-induced increase in abundance of mRNA level for actin-bundling/rigidifying protein fimbrin [35] and actin protein [12] has been reported. In the present study, actin protein was upregulated at $51 \mathrm{~h}$ of treatment in $\mathrm{Al}$-tolerant PI 416937, whereas alpha tubulin was downregulated at 51 and $72 \mathrm{~h}$ (Table 1). In Al-sensitive Young, alpha tubulin was upregulated at $51 \mathrm{~h}$ and downregulated at $72 \mathrm{~h}$ and tubulin beta-3 was upregulated at $72 \mathrm{~h}$ (Table 2). These results show that the two genotypes differ in expression of cytoskeletal proteins under $\mathrm{Al}$ stress. However, how this dynamics relates to $\mathrm{Al}$-induced cytoskeleton stabilization and reorientation that leads to root growth inhibition is yet to be determined. It has been shown that $\mathrm{Al}$-induces mechanical rigor/stability in actin networks of soybean root cells [33]. Thus, the upregulation of actin protein in Altolerant PI 416937 could be an adaptive response to $\mathrm{Al}$ stress. New actin networks could form from newly synthesized actin protein and compensate for networks stabilized by Al. Apart from cytoskeleton proteins, one important protein related to cell division, BRAC1, was upregulated in PI 416937 at $72 \mathrm{~h}$ of treatment. BRAC1 is a DNA damage and cell cycle control protein and its homolog is a breast cancer inhibitor in human [36]. DNA damage is one mechanism of $\mathrm{Al}$ mediated cellular injury [18], suggesting BRAC1 might be an important novel candidate biomarker for plant Al-tolerance.

3.5. Organic Acids Biosynthesis Enzymes. In response to $\mathrm{Al}$ stress, root accumulation and secretion of organic acids increase particularly in Al-tolerant plant genotypes [21, 3739 ], which in most cases is preceded by an increase in expression and activities of enzymes involved in their biosynthesis $[12,39]$. However, the particular TCA cycle enzyme(s) activated by $\mathrm{Al}$ and the organic acid anions modulated are 


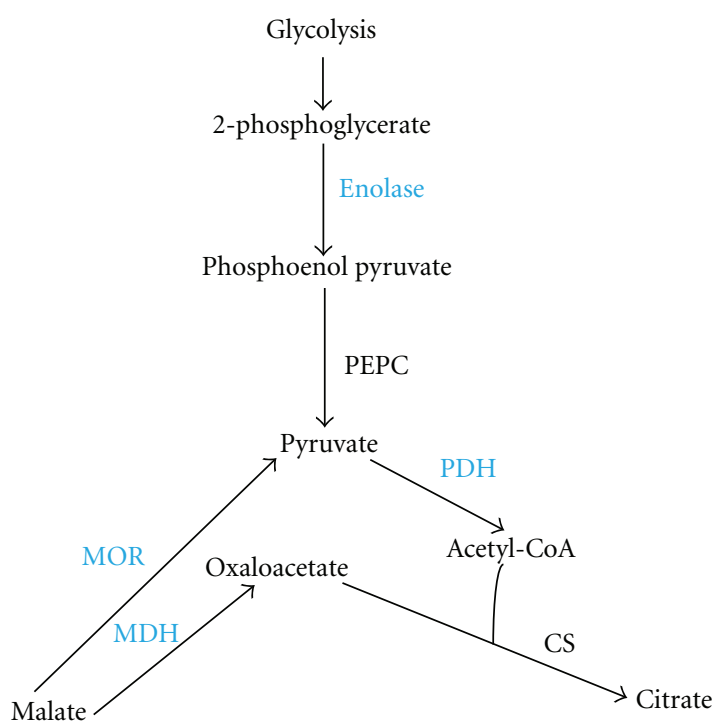

Figure 6: Diagrammatic representation of enzymes involved in citrate synthesis upregulated in Al-tolerant PI 416937. Enzymes in blue color are those upregulated. PEPC: phosphoenol pyruvate carboxylase; PDH: pyruvate dehydrogenase; CS: citrate synthase; MOR: malate oxidoreductase; MDH: malate dehydrogenase.

species specific $[39,40]$. For example, in $\mathrm{Al}$-tolerant microbe (Pseudomonas fluorescens) that depends on oxalate for $\mathrm{Al}$ detoxification, $\mathrm{Al}$ reconfigures the enzymatic reactions of the TCA cycle in favor of the synthesis of glyoxylate-a precursor for oxalate, by upregulating isocitrate layse and downregulating isocitrate dehydrogenase and $\alpha$ ketoglutarate dehydrogenase complex [40]. At the physiological level, soybean $\mathrm{Al}$-tolerance is correlated with increased levels of tissue citrate accumulation and secretion [20,21]. Nonetheless, the specific TCA cycle enzymes that modulate organic acid metabolism in soybean in response to $\mathrm{Al}$ stress have not been identified. Here, we provide the first evidence at protein expression level that show $\mathrm{Al}$ simultaneously induces enolase 1 (spot 20), malate dehydrogenase (spot 42), malate oxidoreductase (spot 18), and pyruvate dehydrogenase E1 (spot 35) (Table 1), in roots of Al-tolerant soybean PI 416937. None of these enzymes was triggered by $\mathrm{Al}$ in the $\mathrm{Al}-$ sensitive Young underscoring the specificity of the response to Al-tolerance mechanism. All of these enzymes contribute to citrate biogenesis (Figure 6), which could explain the increased citrate accumulation and secretion observed in Al-tolerant PI 416937 under Al stress by Silva et al. [21].

Engineering enzymes of the TCA cycle have been the focus of one aspect of plant Al-tolerance research for over a decade. Transgenic upregulation of individual TCA cycle enzymes such as malate dehydrogenase, citrate synthase and phosphoenolpyruvate carboxylase (PEPC) have had some success in producing transgenic plants with enhanced $\mathrm{Al}$ tolerance [41-44]. We speculate that concomitant overexpression of several of these enzymes, as exemplified by natural plant defense response in our study, might be a plausible genetic engineering strategy for developing transgenic crops adapted to high $\mathrm{Al}$ soils. A net increase in cellular citrate level is a balance of its formation and degradation. Therefore, transgenic downregulation of enzymes involved in its breakdown is an alternative scenario for improving plant $\mathrm{Al}$-tolerance. While there is no experimental data available regarding how such transgenic plants would perform under nonstressful environment, improved Altolerance level has been observed in yeast mutants null for citrate degrading enzymes [45]. Also in Al-tolerant maize, Piñeros et al. [46] observed Al-induced reduction in the activity of isocitrate dehydrogenase (a citrate degrading enzyme), which paralleled an increase in root citrate level.

3.6. Signal Transduction and Gene Regulation Proteins. Perception of stress signal and subsequent changes in gene expression, cell metabolism, and physiology are key events in plant adaptation response to a stress factor. Al-signaling pathway has not been elucidated yet with the exception of the identification of one protein (cell wall associated kinase 1, WAK 1) as a possible component of Al signal transduction pathway [47]. Serine/theorine protein kinase and protein phosphatase $2 \mathrm{~A}$, both with signaling function, were identified in the present study. Both were upregulated in Al-tolerant PI 416937 and serine/theorine kinase in Alsensitive Young. Earlier proteome analysis studies suggest that G-protein or GTP binding protein is involved in $\mathrm{Al}$ signaling $[22,24]$. No change in the expression level of this protein was observed in the present study. However, the activity of G-protein coupled receptor is controlled by its phosphorylation state, which in turn is attenuated by protein kinase and phosphatase. The upregulation of serine/theorine protein kinase and protein phosphatase $2 \mathrm{~A}$ might therefore have relevance in $\mathrm{Al}$ stress signaling. ROS signaling 14-3-3-like protein (spots 55 \& 64) was upregulated in PI416937, but downregulated in Young. One transcription factor CREB binding (cAMP element binding) protein (spot 23) was upregulated in PI 416937. CREB binds to CRE (cAMP responsive element) and regulates the transcription of several genes. It modulates several physiological functions including brain memory in human [48], but its role in plant system has not been well documented. Nevertheless, the fact that it regulates the expression of several genes makes it an interesting putative gene for $\mathrm{Al}$ stress tolerance.

3.7. Chaperone and Protease Proteins. Several chaperones, protease, and proteasome subunit proteins were upregulated in both genotypes. These proteins are crucial for survival of biota under adversev conditions and respond to various biotic and abiotic stress factors including $\mathrm{Al}$ [24]. They play a role in protein folding, translocation, degradation, and assembly both under normal and stress conditions [49]. Stress conditions increase the activity of these proteins by altering the intricate balances in cellular protein synthesis and turnover. 


\section{Conclusion}

Aluminum induced a distinct protein profile changes in $\mathrm{Al}$ tolerant and Al-sensitive soybean genotypes. The Al-tolerant genotype PI 416937 expressed multitude of Al-tolerancespecific proteins when mildly intoxicated with $\mathrm{Al}$, whereas the sensitive genotype Young lacks such $\mathrm{Al}$ specific response. The comparative proteome analysis enabled us to identify two enzyme categories namely, enzymes of the antioxidation and detoxification systems and organic acids biosynthesis pathway as important players in soybean Al-tolerance. We also identified two novel proteins, BRAC1: a DNA damage control and cell cycle regulator, and CREB: transcription factor, which might contribute to soybean adaptation mechanisms to Al toxicity. Increased organic acid synthesis, accumulation, and root secretion are the well-known physiological mechanisms of plant Al-tolerance. At the molecular level, attempts to engineer Al-tolerant plants by modulating the activities of individual organic acid biosynthesis enzymes have produced encouraging results [41-44]. In the present study, we observed a concurrent upregulation of several organic acid biosynthesis enzymes in Al-tolerant soybean PI 416937 in response to Al stress which suggests that simultaneous transgenic over-expression of these enzymes might be a more robust genetic engineering strategy for developing $\mathrm{Al}$-tolerant plants than the engineering one enzyme at a time paradigm.

\section{Abbreviations}

\begin{tabular}{|c|c|}
\hline 2D DIGE: & $\begin{array}{l}\text { two-dimensional differential in gel } \\
\text { electrophoresis }\end{array}$ \\
\hline IEF: & isoelctro focusing \\
\hline MALDI-TOF MS: & $\begin{array}{l}\text { Matrix-assisted laser desorption } \\
\text { ionization-time of flight mass } \\
\text { spectrometry }\end{array}$ \\
\hline IPG: & Immobilized pH gradient \\
\hline SDS-PAGE: & $\begin{array}{l}\text { Sodium dodecyl sulfate polyacrylamide } \\
\text { gel electrophoresis }\end{array}$ \\
\hline DTT: & Dithiothreitol \\
\hline CHAPS: & $\begin{array}{l}\text { 3-[(3-Cholamidopropyl }) \\
\text { dimethylammonio }]-1- \\
\text { propanesulfonate }\end{array}$ \\
\hline ROS: & Reactive oxygen species \\
\hline BRAC1: & Breast cancer 1 gene \\
\hline CREB: & $\begin{array}{l}\text { cAMP response element-binding } \\
\text { transcription factor }\end{array}$ \\
\hline CI\%: & Confidence interval percentage \\
\hline TCA cycle: & Tricarboxylic acid cycle. \\
\hline
\end{tabular}

\section{Acknowledgments}

This research was supported in part by NSF/EPSCOR Grant no. 05026 and the School of Agricultural and Environmental Sciences, Alabama A\&M University. The authors are grateful to Drs. L. Gallagher of UCD and M. Saghai-Maroof of VT for their valuable comments on the earlier version of this manuscript. Contributed by, the Agricultural Experiment Station, Alabama A\&M University.

\section{References}

[1] J. V. Magalhaes, "Aluminum tolerance genes are conserved between monocots and dicots," Proceedings of the National Academy of Sciences of the United States of America, vol. 103, no. 26, pp. 9749-9750, 2006.

[2] S. R. Valle, J. Carrasco, D. Pinochet, and D. F. Calderini, "Grain yield, above-ground and root biomass of Al-tolerant and Al-sensitive wheat cultivars under different soil aluminum concentrations at field conditions," Plant and Soil, vol. 318, no. 1-2, pp. 299-310, 2009.

[3] G. R. Rout, S. Samantaray, and P. Das, "Aluminium toxicity in plants: a review," Agronomie, vol. 21, no. 1, pp. 3-21, 2001.

[4] Z. Rengel and W. H. Zhang, "Role of dynamics of intracellular calcium in aluminium-toxicity syndrome," New Phytologist, vol. 159, no. 2, pp. 295-314, 2003.

[5] E. B. Blancaflor, D. L. Jones, and S. Gilroy, "Alterations in the cytoskeleton accompany aluminum-induced growth inhibition and morphological changes in primary roots of maize," Plant Physiology, vol. 118, no. 1, pp. 159-172, 1998.

[6] M. Amenós, I. Corrales, C. Poschenrieder, P. Illéš, and F. Baluška, "Different effects of aluminum on the actin cytoskeleton and brefeldin a-sensitive vesicle recycling in root apex cells of two maize varieties differing in root elongation rate and aluminum tolerance," Plant and Cell Physiology, vol. 50, no. 3, pp. 528-540, 2009.

[7] K. A. Schreiner, J. Hoddinott, and G. J. Taylor, "Aluminuminduced deposition of (1,3)- $\beta$-glucans (callose) in Triticum aestivum L," Plant and Soil, vol. 162, no. 2, pp. 273-280, 1994.

[8] Y. Yamamoto, Y. Kobayashi, S. R. Devi, S. Rikiishi, and H. Matsumoto, "Aluminum toxicity is associated with mitochondrial dysfunction and the production of reactive oxygen species in plant cells," Plant Physiology, vol. 128, no. 1, pp. 63-72, 2002.

[9] W. J. Horst, "The role of the apoplast in aluminum toxicity and resistance of higher plants," Zeitschrift für Pflanzenernärung und Bodenkunde, vol. 158, pp. 419-428, 1995.

[10] S. Doncheva, M. Amenós, C. Poschenrieder, and J. Barceló, "Root cell patterning: a primary target for aluminium toxicity in maize," Journal of Experimental Botany, vol. 56, no. 414, pp. 1213-1220, 2005.

[11] C. Poschenrieder, B. Gunsé, I. Corrales, and J. Barceló, "A glance into aluminum toxicity and resistance in plants," Science of the Total Environment, vol. 400, no. 1-3, pp. 356368, 2008.

[12] S. Zhou, R. Sauvé, and T. W. Thannhauser, "Proteome changes induced by aluminum stress in tomato roots," Journal of Experimental Botany, vol. 57, pp. 4201-4213, 2009.

[13] J. F. Ma, P. R. Ryan, and E. Delhaize, "Aluminium tolerance in plants and the complexing role of organic acids," Trends in Plant Science, vol. 6, no. 6, pp. 273-278, 2001.

[14] P. S. Kidd, M. Llugany, C. Poschenrieder, B. Gunsé, and J. Barceló, "The role of root exudates in aluminium resistance and silicon-induced amelioration of aluminium toxicity in three varieties of maize (Zea mays L.)," Journal of Experimental Botany, vol. 52, no. 359, pp. 1339-1352, 2001.

[15] R. Tolrà, J. Barceló, and C. Poschenrieder, "Constitutive and aluminium-induced patterns of phenolic compounds in two maize varieties differing in aluminium tolerance," Journal of Inorganic Biochemistry, vol. 103, no. 11, pp. 1486-1490, 2009.

[16] D. Duressa, K. Soliman, and E. Cebert, "Protein and polyphenol profile changes in soybean roots under aluminum stress," International Journal of Plant Physiology and Biochemistry, vol. 2, no. 3, pp. 38-45, 2010. 
[17] D. M. Pellet, L. A. Papernik, and L. V. Kochian, "Multiple aluminum-resistance mechanisms in wheat roles of root apical phosphate and malate exudation," Plant Physiology, vol. 112, no. 2, pp. 591-597, 1996.

[18] L. V. Kochian, O. A. Hoekenga, and M. A. Piñeros, "How do crop plants tolerate acid soils? Mechanisms of aluminum tolerance and phosphorous efficiency," Annual Review of Plant Biology, vol. 55, pp. 459-493, 2004.

[19] C. M. Bianchi-Hall, T. E. Carter, M. A. Bailey et al., "Aluminum tolerance associated with quantitative trait loci derived from soybean PI 416937 in hydroponics," Crop Science, vol. 40, no. 2, pp. 538-545, 2000.

[20] Z. M. Yang, M. Sivaguru, W. J. Horst, and H. Matsumoto, "Aluminium tolerance is achieved by exudation of citric acid from roots of soybean (Glycine max)," Physiologia Plantarum, vol. 110, no. 1, pp. 72-77, 2000.

[21] I. R. Silva, T. J. Smyth, C. D. Raper, T. E. Carter, and T. W. Rufty, "Differential aluminum tolerance in soybean: an evaluation of the role of organic acids," Physiologia Plantarum, vol. 112, no. 2, pp. 200-210, 2001.

[22] Q. Yang, Y. Wang, J. Zhang, W. Shi, C. Qian, and X. Peng, "Identification of aluminum-responsive proteins in rice roots by a proteomic approach: cysteine synthase as a key player in Al response," Proteomics, vol. 7, no. 5, pp. 737-749, 2007.

[23] S. Zhou, R. Sauve, and T. W. Thannhauser, "Aluminum induced proteome changes in tomato cotyledons," Plant Signaling and Behavior, vol. 4, no. 8, pp. 769-772, 2009.

[24] Y. Zhen, J. L. Qi, S. S. Wang et al., "Comparative proteome analysis of differentially expressed proteins induced by $\mathrm{Al}$ toxicity in soybean," Physiologia Plantarum, vol. 131, no. 4, pp. 542-554, 2007.

[25] W. J. Hurkman and C. K. Tanaka, "Solubilization of plant membrane proteins for analysis by two-dimensional gel electrophoresis," Plant Physiology, vol. 81, pp. 802-806, 1986.

[26] M. M. Bradford, "A rapid and sensitive method for rapid quantification of micrograquantities of protein utilizing the principle of protein-dye binding," Anals of Biochemistry, vol. 72, pp. 248-254, 1976.

[27] N. L. Houston, M. Hajduch, and J. J. Thelen, "Quantitative proteomics of seed filling in castor: comparison with soybean and rapeseed reveals differences between photosynthetic and nonphotosynthetic seed metabolism," Plant Physiology, vol. 151, no. 2, pp. 857-868, 2009.

[28] A. Giannakoula, M. Moustakas, T. Syros, and T. Yupsanis, "Aluminum stress induces up-regulation of an efficient antioxidant system in the Al-tolerant maize line but not in the Alsensitive line," Environmental and Experimental Botany, vol. 67, no. 3, pp. 487-494, 2010.

[29] I. R. Silva, T. J. Smyth, D. F. Moxley, T. E. Carter, N. S. Allen, and T. W. Rufty, "Aluminum accumulation at nuclei of cells in the root tip. Fluorescence detection using lumogallion and confocal laser scanning microscopy," Plant Physiology, vol. 123, no. 2, pp. 543-552, 2000.

[30] C. Cobbett and P. Goldsbrough, "Phytochelatins and metallothioneins: roles in heavy metal detoxification and homeostasis," Annual Review of Plant Biology, vol. 53, pp. 159-182, 2002.

[31] S. Saka, W. Aouacheri, and C. Abdennour, "The capacity of glutathione reductase in cell protection from the toxic effect of heated oils," Biochimie, vol. 84, no. 7, pp. 661-665, 2002.
[32] M. Sivaguru, F. Baluška, D. Volkmann, H. H. Felle, and W. J. Horst, "Impacts of aluminum on the cytoskeleton of the maize root apex. Short-term effects on the distal part of the transition zone," Plant Physiology, vol. 119, no. 3, pp. 10731082, 1999.

[33] S. Grabski and M. Schindler, "Aluminum induces rigor within the actin network of soybean cells," Plant Physiology, vol. 108, no. 3, pp. 897-901, 1995.

[34] M. Sivaguru, S. Pike, W. Gassmann, and T. I. Baskin, "Aluminum rapidly depolymerizes cortical microtubules and depolarizes the plasma membrane: evidence that these responses are mediated by a glutamate receptor," Plant and Cell Physiology, vol. 44, no. 7, pp. 667-675, 2003.

[35] R. Cruz-Ortega, J. C. Cushman, and J. D. Ownby, "cDNA clones encoding 1,3- $\beta$-glucanase and a fimbrin-like cytoskeletal protein are induced by $\mathrm{Al}$ toxicity in wheat roots," Plant Physiology, vol. 114, no. 4, pp. 1453-1460, 1997.

[36] L. Kadouri, A. Hubert, Y. Rotenberg et al., "Cancer risks in carriers of the BRCA1/2 Ashkenazi founder mutations," Journal of Medical Genetics, vol. 44, no. 7, pp. 467-471, 2007.

[37] T. Watanabe, M. Osaki, H. Yano, and I. Rao, "Internal mechanisms of plant adaptation to aluminum toxicity and phosphorus starvation in three tropical forages," Journal of Plant Nutrition, vol. 29, no. 7, pp. 1243-1255, 2006.

[38] X. F. Li, J. F. Ma, and H. Matsumoto, "Pattern of aluminuminduced secretion of organic acids differs between rye and wheat," Plant Physiology, vol. 123, no. 4, pp. 1537-1543, 2000.

[39] J. F. De Carvalho Gonçalves, J. Cambraia, P. R. Mosquim, and E. F. Araújo, "Aluminum effect on organic acid production and accumulation in sorghum," Journal of Plant Nutrition, vol. 28, no. 3, pp. 507-520, 2005.

[40] R. D. Hamel and V. D. Appanna, "Modulation of TCA cycle enzymes and aluminum stress in Pseudomonas fluorescens," Journal of Inorganic Biochemistry, vol. 87, no. 1, pp. 1-8, 2001.

[41] M. Tesfaye, S. J. Temple, D. L. Allan, C. P. Vance, and D. A. Samac, "Overexpression of malate dehydrogenase in transgenic alfalfa enhances organic acid synthesis and confers tolerance to aluminum," Plant Physiology, vol. 127, no. 4, pp. 1836-1844, 2001.

[42] V. M. Anoop, U. Basu, M. T. McCammon, L. McAlister-Henn, and G. J. Taylor, "Modulation of citrate metabolism alters aluminum tolerance in yeast and transgenic canola overexpressing a mitochondrial citrate synthase," Plant Physiology, vol. 132, no. 4, pp. 2205-2217, 2003.

[43] P. Barone, D. Rosellini, P. LaFayette, J. Bouton, F. Veronesi, and W. Parrott, "Bacterial citrate synthase expression and soil aluminum tolerance in transgenic alfalfa," Plant Cell Reports, vol. 27, no. 5, pp. 893-901, 2008.

[44] H. H. Begum, M. Osaki, T. Watanabe, and T. Shinano, "Mechanisms of aluminum tolerance in phosphoenolpyruvate carboxylase transgenic rice," Journal of Plant Nutrition, vol. 32, no. 1, pp. 84-96, 2009.

[45] V. M. Anoop, U. Basu, M. T. McCammon, L. McAlister-Henn, and G. J. Taylor, "Modulation of citrate metabolism alters aluminum tolerance in yeast and transgenic canola overexpressing a mitochondrial citrate synthase," Plant Physiology, vol. 132, no. 4, pp. 2205-2217, 2003.

[46] M. A. Piñeros, J. V. Magalhaes, V. M. Carvalho Alves, and L. V. Kochian, "The physiology and biophysics of an aluminum tolerance mechanism based on root citrate exudation in maize," Plant Physiology, vol. 129, no. 3, pp. 1194-1206, 2002. 
[47] M. Sivaguru, B. Ezaki, Z. H. He et al., "Aluminum-induced gene expression and protein localization of a cell wallassociated receptor kinase in Arabidopsis," Plant Physiology, vol. 132, no. 4, pp. 2256-2266, 2003.

[48] W. A. Carlezon, R. S. Duman, and E. J. Nestler, "The many faces of CREB," Trends in Neurosciences, vol. 28, no. 8, pp. 436445, 2005.

[49] W. Wang, B. Vinocur, O. Shoseyov, and A. Altman, "Role of plant heat-shock proteins and molecular chaperones in the abiotic stress response," Trends in Plant Science, vol. 9, no. 5, pp. 244-252, 2004. 

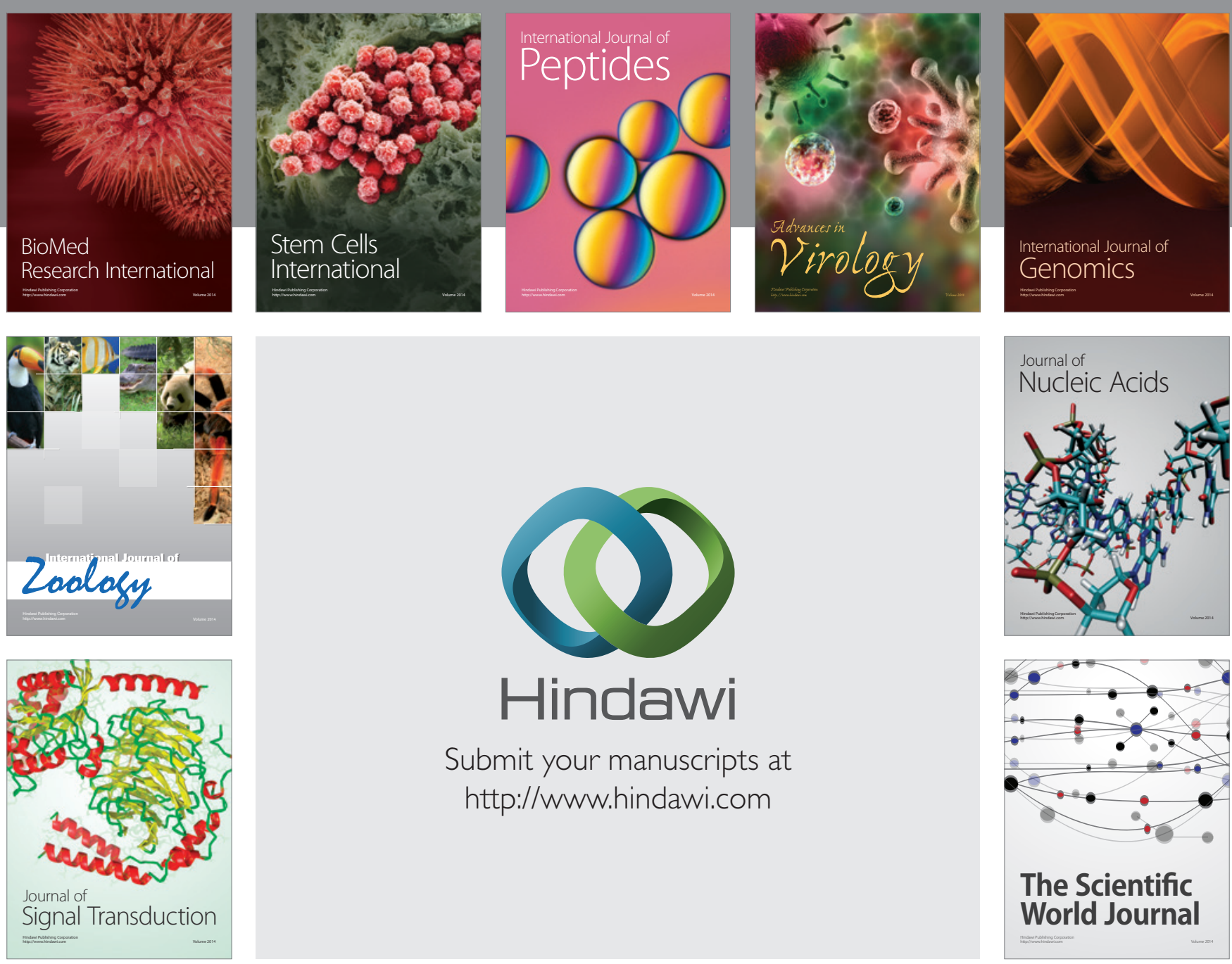

Submit your manuscripts at

http://www.hindawi.com
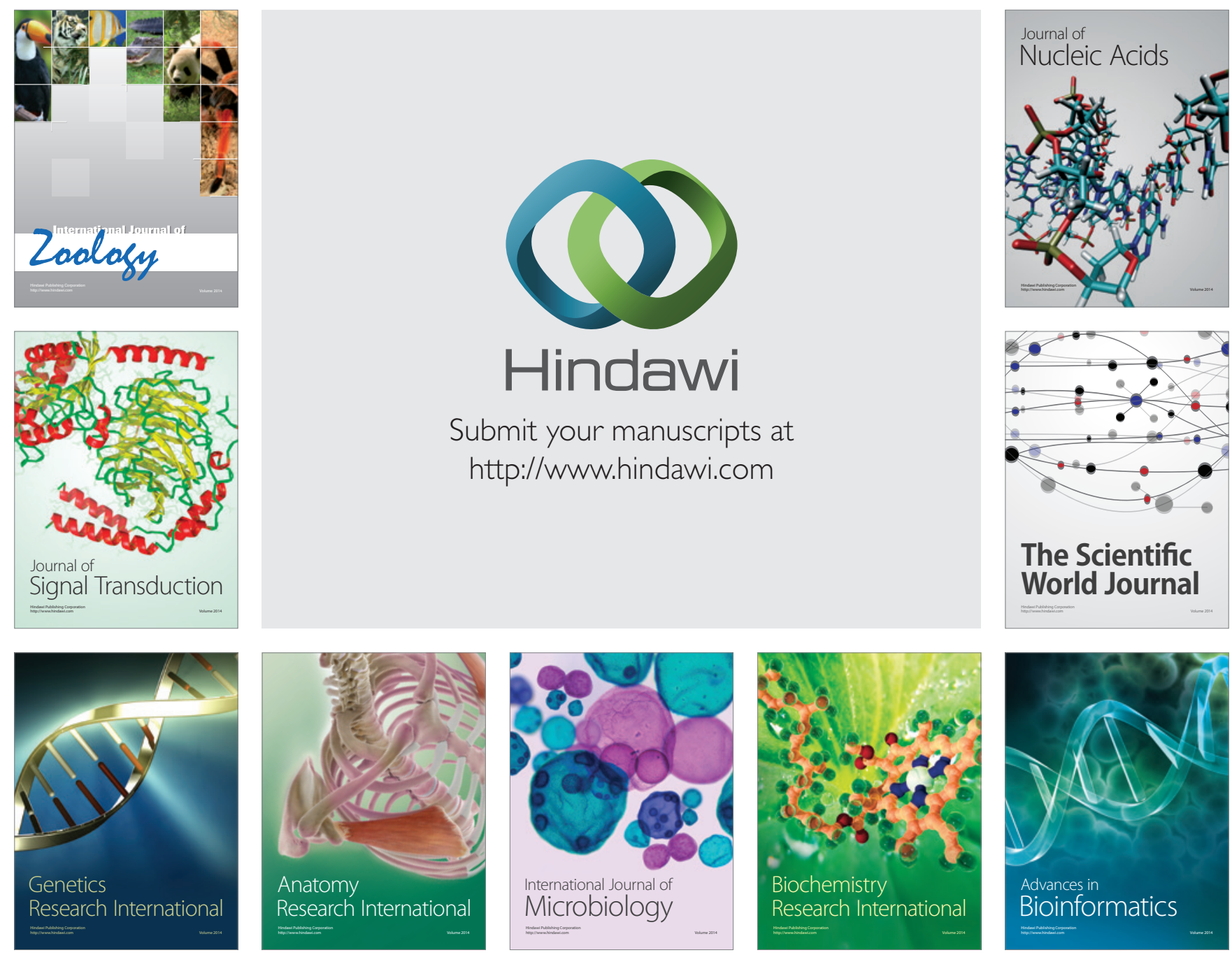

The Scientific World Journal
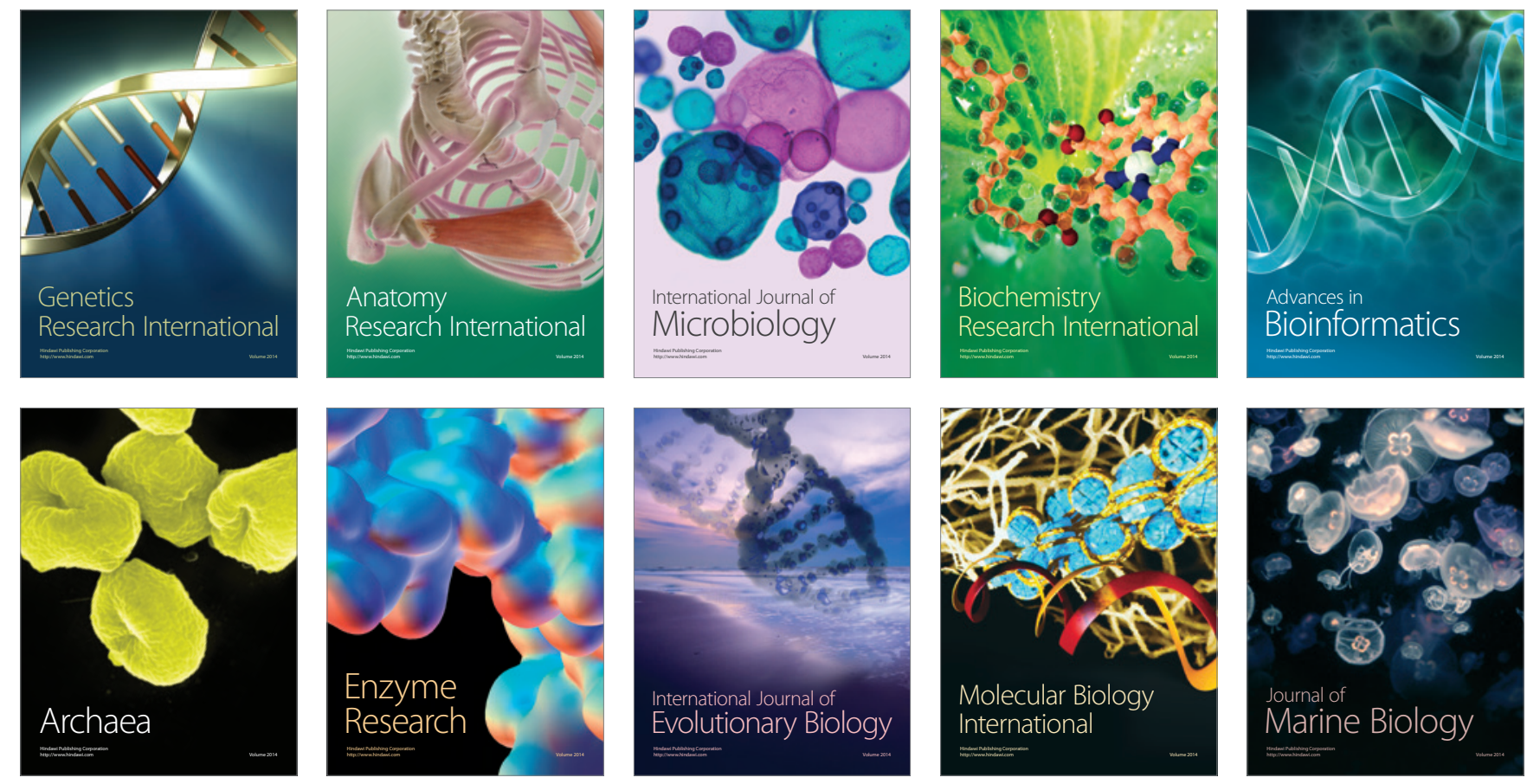